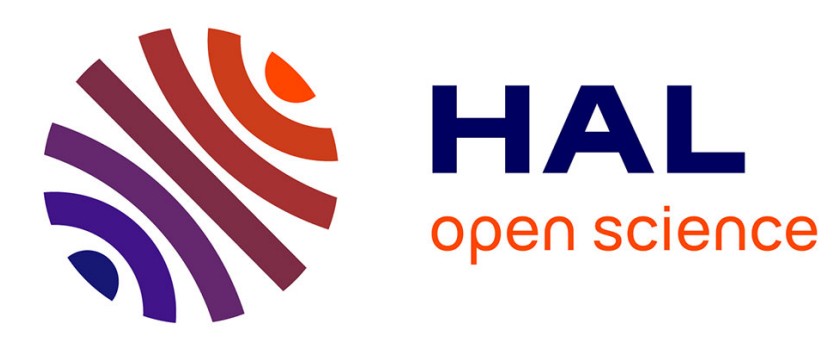

\title{
Creole learner varieties in the past and in the present: implications for creole development
}

Bettina Migge, Margot van den Berg

\section{To cite this version:}

Bettina Migge, Margot van den Berg. Creole learner varieties in the past and in the present: implications for creole development. Langage, Interaction et Acquisition / Language, Interaction and Acquisition , 2009, 1 (1), pp.253-282. hal-01496570

\section{HAL Id: hal-01496570 \\ https://hal.science/hal-01496570}

Submitted on 27 Mar 2017

HAL is a multi-disciplinary open access archive for the deposit and dissemination of scientific research documents, whether they are published or not. The documents may come from teaching and research institutions in France or abroad, or from public or private research centers.
L'archive ouverte pluridisciplinaire HAL, est destinée au dépôt et à la diffusion de documents scientifiques de niveau recherche, publiés ou non, émanant des établissements d'enseignement et de recherche français ou étrangers, des laboratoires publics ou privés. 


\section{Research Repository UCD}

Provided by the author(s) and University College Dublin Library in accordance with publisher policies. Please cite the published version when available.

\begin{tabular}{|c|l|}
\hline Title & $\begin{array}{l}\text { Creole learner varieties in the past and in the present: } \\
\text { implications for creole development }\end{array}$ \\
\hline Author(s) & Bettina, Migge; van den Berg, Margot \\
\hline $\begin{array}{c}\text { Publication } \\
\text { date }\end{array}$ & $2009-09$ \\
\hline $\begin{array}{c}\text { Publication } \\
\text { information }\end{array}$ & $\begin{array}{l}\text { Acquisition et interaction en langue étrangère; Language, } \\
\text { Interaction and Acquisition, 1 (1): 253-281 }\end{array}$ \\
\hline $\begin{array}{c}\text { Publisher } \\
\text { John Benjamins Publishing }\end{array}$ \\
\hline $\begin{array}{c}\text { Link to online } \\
\text { version }\end{array}$ & http://aile.revues.org/4524 \\
\hline $\begin{array}{c}\text { Item } \\
\text { information }\end{array}$ & http://hdl.handle.net/10197/5851 \\
\hline
\end{tabular}

Downloaded 2017-03-21T20:21:32Z

The UCD community has made this article openly available. Please share how this access benefits you. Your story matters! (@ucd_oa)

Some rights reserved. For more information, please see the item record link above.

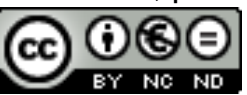




\title{
Creole learner varieties in the past and in the present:
}

Implications for Creole development

Bettina Migge \& Margot van den Berg ${ }^{1}$

University College Dublin Radboud University Nijmegen

\begin{abstract}
Second language (L2) acquisition is widely assumed to have played a role in the emergence of creole genesis. However, the impact of L2 acquisition may not have been restricted to its genesis. In Surinam, newcomers outnumbered locally-born speakers of the Creole throughout the $18^{\text {th }}$ century. To date we know little about the effects that this disproportion of non-native vs. native speakers may have had in the initial and subsequent stages of development of these Creoles. In this paper we combine historical and contemporary data in order to investigate the impact of L2 acquisition and use on developing creoles. We examine several linguistic features in contemporary native (L1) as well as non-native (L2) creole speech in order to reveal the differences in the underlying L1 and L2 systems. These are then compared with their equivalents in the available historical sources. The findings suggest that L2 acquisition affected the development of some linguistic subsystems while others appear little influenced.
\end{abstract}

Key Words: Surinamese Creoles, creolization, negation, tense \& aspect, L1 \& L2 acquisition

\section{Introduction}

Discussions about the role of second language (L2) learning strategies have a long history in the literature on the genesis and development of creoles. Since the beginning of the $21^{\text {st }}$ century there is renewed interest in the study of the shared processes involved in both L2 learning and creole genesis (Winford 2003; Lefebvre et al. 2006; Siegel 2008).

L2 acquisitionists working with Clive Perdue and Wolfgang Klein in particular provide a valuable framework for comparing proto-typical L2 practices and developing creoles. According to these scholars, outcomes of second language learning, so-called learner varieties, are systems, characterized by a particular lexical repertoire and by a particular interaction of organizational principles that principally differ from native varieties in their underlying organizational principles (Klein \& Perdue 1997; Dimroth \& Starren 2003; Hendriks 2005).

In pidgin and creole $(\mathrm{P} / \mathrm{C})$ studies, the nature of learner varieties and their role in shaping creole grammars have hardly been explicitly studied because there is a longstanding bias towards discovering the grammatical system of creoles, and because locally-born children are traditionally assumed to be the main agents of creole genesis. Following Bickerton (1981), it is widely assumed that the structural

\footnotetext{
${ }^{1}$ We would like to thank two anonymous reviewers and the editor of this volume, Sandra Benazzo, for their insightful comments and criticism on earlier versions of this paper. All remaining errors are the responsibility of the authors.

bettinamigge@ucd.ie; m.v.d.berg@1et.ru.nl
} 
elaboration differentiating a complex creole from its simple pidgin ancestor results from nativization, namely the acquisition of native speakers by a language. While foreign-born adults (non-native speakers) contribute innovative features to the developing language, locally-born children play a crucial role, via first language acquisition, in stabilizing and elaborating the linguistic system (see for example DeGraff 1999 among others).

This classic view of creole development has in recent years been further developed by researchers working on expanded Pacific Pidgins and Hawai'ian (cf. Roberts 2000; Siegel 2008). For instance, Siegel (2008) posits a three-generational rather than a two-generational model, and argues that substrate calquing and second language use, rather than first language acquisition, played an important role in the development of creoles. He posits the following model: that the first generation who was dominant in their ancestral language introduced new morphosyntactic features to the pidgin through substrate calquing. The second generation, who were bilingual in an ancestral language and in the emerging contact language and who also made frequent use of the pidgin, assigned new functions to such features mostly based on models found in their ancestral languages. Finally, the third generation who were mostly monolingual in the contact variety further systematized and firmly established their use.

In the case of the Surinamese Creoles, the picture is more complex and a similar clear-cut three generational development model finds little support (cf. Arends 1989; Essegbey \& Bruyn to appear; Migge \& Winford 2009; Kramer 2009; van den Berg 2007). ${ }^{2}$ However, Siegel's emphasis on the role of substrate influence via transfer in the development of creoles is clearly of interest for the Surinamese context. Demographic data suggest that Sranan was being learned and practiced mostly as an L2 by newly arriving enslaved Africans, free Europeans and later indentured labourers for a considerable amount of time after its initial emergence. Even in late $18^{\text {th }}$ century Surinam, over a century after initial colonization, only $30 \%$ of the black population was locally-born (Arends 1995: 269). The Maroon Creoles nativized more quickly, but they, particularly Ndyuka and to a lesser degree the other Eastern Maroon varieties, have also been and continue to be practiced as L2 varieties (cf. Léglise 2007 for the modern context). To date it is still unclear what effect this numerical dominance of non-native over native speakers has had on the development of these creoles.

In this paper we will take up this issue, drawing on historical as well as contemporary data. In contrast to other creoles, a remarkable corpus of $18^{\text {th }}$ century language materials in and on Sranan is available that provides us with a unique window on $18^{\text {th }}$ century Sranan language practices. ${ }^{3}$ The contemporary data come from recordings and discussion with native and non-native speakers of the Creoles of Surinam in French Guiana. In order to explore the similarities and differences in the

\footnotetext{
${ }^{2}$ Note that Smith (2009) and Veenstra (2006) propose a more abrupt scenario that is more in line with a three generational development model.

${ }^{3}$ Historical texts for the Maroon Creoles are much less substantial, but due to close similarities between these languages, the Early Sranan corpus can also provide important insights into the development of the Maroon Creoles.
} 
underlying L1 and L2 systems, we first examine three linguistic features, namely negation, and imperfective and past time marking, in the contemporary varieties and then compare them with their Early Sranan equivalents. The aim of this study is to improve our understanding of the role and relative impact of strategies of second language learning and use on the development of creole grammar.

The paper is organized as follows. Part One provides some background on the data and outlines the research methodology in more detail. In Parts Two to Four we compare the distribution of the three linguistic features in our contemporary and historical corpora. Part Five summarizes the findings and discusses the implications for theories of creole development.

\section{Data \& Methodology}

\section{1. The contemporary language data}

The French overseas department of French Guiana (Guyane Française) is highly multilingual. Current estimates put the number to about 30 languages belonging to several families of languages (cf. Léglise $\&$ Migge 2006). Besides French, the official language, they include Amerindian languages from the Cariban (Kali'na, Wayana), Tupi-Guarani (Emerillon, Wayampi), and Arawak (Lokono, Palikur) family of languages, various European languages such as Brazilian Portuguese, (Surinamese) Dutch and Spanish, English-lexified creoles (Aluku, Ndyuka, Pamaka, Saamaka, Sranan Tongo, Guyanese Creole), French-lexified creoles (the Creoles of French Guiana, Martinique and Guadeloupe \& Haitian Creole), and Asian languages like Hmong and varieties of Chinese. In the last 30 years, French Guiana has received considerable numbers of migrants from the Guiana region (Guyana, Surinam, Brazil) and from outside of the region (Haiti, China), and processes of urbanization have given rise to a fair amount of internal migration.

Speakers of Surinamese Creoles are at the centre of such migration movements. They currently constitute about $40 \%$ of the overall population and make up an even higher proportion in the western part of the department. The three related Eastern Maroon Creoles (EMC) Aluku, Ndyuka and Pamaka are spoken natively by more than $30 \%$ of the population (Léglise 2007). Native speakers of Sranan Tongo are restricted to the few Arawak villages and a few Kali'na villages.

The Creoles of Surinam are also widely used as a lingua franca in western French Guiana where they are locally referred to by the generalizing terms Takitaki or Businenge Tongo which may refer to all the Creoles of Surinam or just to a subset such as the three related EMCs (cf. Léglise \& Migge 2006). A school survey showed that more than $65 \%$ of $6^{\text {th }}$ grade children in the west declare speaking Ndyuka or Takitaki as an L2 (Léglise 2007).

The data for this study come from a wide range of interactions involving persons of European, Guianese, Haitian, Chinese, Brasilian and Amerindian (Kali'na) origin. Some of the interactions had an interview character while others were service encounters or informal chats (cf. Migge \& Leglise in prep.). People's competence in the language, learning trajectories and usage patterns also differ. One 
person was essentially at the one-word stage while most others had progressed to an intermediate or high level of competence. Some people learned 'Takitaki' in their youth while others only learned it later in adult life. Finally, some used 'Takitaki' only for a limited number of work-related interactions while others used it regularly for a wide range of interactions, including peers, partners, in-laws, and some formal interactions.

\subsection{Historical sources}

The texts that were consulted for the present study were retrieved from the Sranan Section of the Surinam Creole Archive. ${ }^{4}$ They include a) religious texts such as bible translations and hymns (Schumann 1781); b) judicial documents such as transcripts of interrogations and witness reports (Court Records); c) official documents such as a peace treaty; d) travel reports and e) documents that were created for the purpose of language instruction such as dictionaries and language manuals by a Moravian missionary (C. L. Schumann) as well as secular persons (J.D. Herlein, P. van Dyk, J. Nepveu and G. C. Weygandt). Because of this variety of text types, variation within and among the texts may correspond to different dimensions, ranging from diachronic to social, stylistic as well as geographical. Furthermore, variation within and among the texts may be linked to the different speech events represented in these texts, ranging from recorded, recalled to imagined and invented. While recorded texts are the most reliable (van den Berg \& Arends 2004), texts belonging to other text types need to be assessed carefully in terms of representativeness and validity. Detailed assessments can be found in the works of Smith (1987), Arends (1989, 1995), Bruyn (1995) and van den Berg (2007) among others. The sources are presented in table 1.

Table 1 The texts in the Sranan section of SUCA that were used in this study

\begin{tabular}{|c|c|c|c|c|c|}
\hline text & year & $\begin{array}{l}\text { document } \\
\text { type }\end{array}$ & page & SR tokens & token total \\
\hline Court Records & $1707-1767$ & dl; we & - & 500 & - \\
\hline Herlein & 1718 & $\mathrm{w} ; \mathrm{dl}$ & 3 & 200 & 400 \\
\hline Nepveu & 1762 & $\mathrm{pt}$ & 12 & 1.900 & 1.900 \\
\hline Van Dyk & $\mathrm{c} 1765$ & $\mathrm{w} ; \mathrm{dl} ; \mathrm{pl}$ & 108 & 14.000 & 28.000 \\
\hline Nepveu & 1770 & $\mathrm{w} ; \mathrm{dl}$ & 8 & 700 & 1.800 \\
\hline Schumann & 1783 & $\mathrm{dl} ; \mathrm{dc}$ & 205 & 20.000 & 40.000 \\
\hline Stedman & 1790 & we & - & 300 & - \\
\hline Weygandt & 1798 & $\mathrm{w} ; \mathrm{dl} ; \mathrm{pl}$ & 144 & 15.000 & 30.000 \\
\hline total & & & 480 & 52.600 & 102.100 \\
\hline
\end{tabular}

\footnotetext{
${ }^{4}$ The Suriname Creole Archive (SUCA) is a joint project of the Radboud University Nijmegen, the University of Amsterdam and the Max Planck Institute Nijmegen supported by NWO (http://suca.ruhosting.nl, under construction).
} 
$(\mathrm{w}=$ word list $; \mathrm{dl}=$ dialogue; $\mathrm{pl}=$ play; $\mathrm{dc}=$ dictionary; $\mathrm{we}=$ Sranan words and expressions in text in another language; $\mathrm{pt}=$ peace treaty)

\section{3. Methodology}

We have selected three morphosyntactic features for comparison between contemporary native and non-native creole speech and Early Sranan: Negation, Imperfective aspect and Past time reference. We focus on these aspects of the verb phrase because they have figured prominently in the literature on L2 learning.

First, we examine these features in contemporary native and non-native creole speech in order to reveal the similarities and differences in the underlying L1 and L2 systems. Subsequently, their Early Sranan equivalents are studied. We posit that similarities between L1 practices and Early Sranan (but not L2 practices) suggest that a feature emerged rapidly and that its emergence was mostly likely not characterized by a protracted period of variation preceding stabilization. By contrast, we take similarities between L2 practices and Early Sranan (but not L1 practices) to be indicative of a slow process of development of the investigated feature; its emergence involved one or more stages, and/or several different models were in competition prior to the feature's stabilization. Similarities between L1, L2 and Early Sranan suggest that the investigated feature may have emerged via converging developmental paths in L1 and L2 acquisition. Differences between L1, L2 and Early Sranan call for other explanations, such as contact-induced changes modelled on languages not encountered in the other setting. For example, Dutch and German may have exerted some influence on (the representation of) Early Sranan, but only (Surinamese) Dutch influences L1 and L2 practices in French Guyana, indirectly through Sranan and directly because some L1 speakers did all or part of their education in Surinam.

\section{Negation}

Negation markers are among the few closed class items that are typically found in the Basic Variety (BV), an early but relatively stable state in the process of spontaneous (adult) second language acquisition (Klein \& Perdue 1997). They tend to precede the part of the utterance over which they have scope and occur at the topic-focus boundary (Klein \& Perdue 1997: 318). Because the placement of negation (and other scope particles) depends to a certain extent on the topic-focus structure of the utterance, and on the position of the elements over which they have scope, its position "indicates which part of the utterance is to be affected by the particle, and its scope can be described as "adjacent and to the right"." (Dimroth \& Watorek 2000: 309).

The expression of negation evolves via the use of holophrastic (or anaphoric) negation in the pre-BV (stage 1), to a focus operator and later topic-focus linker in the BV (stage 2) to forms that correspond more closely to the syntax and morphology of negation in the target language (stage 3 ). But already in the pre-BV, negation is integrated in the utterance structure, as it is either a comment on 
a topic $\mathrm{X}$ or it has in its focus an element $\mathrm{X}$. Once lexical categories and thematic arguments are acknowledged by the learner, the item that expresses negation, the negation operator, begins to act as a focus sensitive operator, being placed in pre-focus (typically pre-verbal) position. When focus is no longer the main drive behind the placement of negation in pre-verbal position, a syntactic motivation is assumed for the placement of negation in this position (see Dimroth et al. 2003).

\section{1. Negation in contemporary $L 1$ varieties}

In the L1 varieties of the EMCs and Sranan clausal negation is expressed by a negation operator or negative particle, $n a ́$ or $\dot{a}(n)$ in the EMCs and no in Sranan, that directly precedes the verb and its auxiliaries (1). However, our EM L1 data involves variation between EMC and Sranan forms. This is most prominent among young urbanized Maroons who are at pains to project an urban identity (cf. Migge 2007).

(1) a. Mi án $\quad$ biibi. (PM 17)

1S NEG believe

'I don't believe it.'

b. No, yu no musu aksi a man tu. (SN 8b)

No, 2S NEG must ask DET man true

'No, you're right, you surely shouldn't ask him.'

Constituent negation is expressed by ná wan 'not one' preceding a constituent that is headed by a noun (2a). When it occurs in combination with clausal negation in the EMCs, the negated constituent does not occur in clause initial position (2b) unless it is clefted.

(2) a. ná wan sani a abi a ini en osu fu den teke beli en. (ND1) NEG one things $3 \mathrm{~s}$ have $\mathrm{LOC}$ in $3 \mathrm{~s}$ house for they take bury $3 \mathrm{~s}$

'He has nothing in his house to bury him with.'

b. I á poy bay ná wan enkii sani. (ND1)

$2 \mathrm{~S}$ NEG can buy NEG one single thing

'You cannot buy a single thing.'

In Sranan, the use of no wan 'not one' is less restricted; the negated constituent can occur in clause initial position without fronting or clefting (3b).

(3) a. èn dati $y u$ no ben gi yu sisa no wan enkri warskow and that $2 \mathrm{~S}$ NEG PAST give your sister NEG one single warning srefi. (SN) 
self

'And you did not give your sister even a single warning.'

b. Ma no wan sukutaki, $\underline{\text { no }} \underline{\text { wan }}$ korkoribromki, noti no but NEG one search-talk NEG one flatter-flower nothing NEG

ben yepi. (from Eersel 2008)

PAST help

'But not a single request, no flattery, nothing helped.'

The negative constituent adds emphasis (cf. Huttar \& Huttar 1994: 253). Compare for instance the sentences in (4): (4a) with constituent negation has an emphatic reading while (4b) without it does not. In (4a), everybody without exclusion is referred to while in (4b) it is implied that only some, usually the majority, are included.

(4) a. Ná wan sama ná o wani. (PM 27) no one person NEG FUT want 'Nobody doesn't want (to do this).'

b. Sama án lobi fa $i$ anga en e libi. (PM 17) person NEG love how $2 \mathrm{~s}$ with $3 \mathrm{~S}$ IMPF live 'People don't like the way you and him live.'

The negative pronoun noti 'nothing' and negative adverb noiti 'never' also require clausal negation if they follow the verb (5).

(5) a. $d a \quad a \quad \underline{n a ́} \quad o \quad$ lei noiti moo. (PM 20) then $3 \mathrm{~S}$ NEG FUT drive never again 'Then he won't transport food for us any more.'

b. $m i \quad \underline{a} n$ be sabi noti. (PM 4)

1S NEG PAST know nothing

'I didn't know anything (about it).'

If they occur in clause initial position, clausal negation is omitted (6).

(6) Noiti de wani a kon fu pasa na wan taa ana sonde denana. (PM 4) never 3P want 3P come for pass $\mathrm{LOC}$ one other hand without 3P hand 'They (government) never want any (monetary) help to go to Maroons without first it going through them.' 


\subsection{Negation in contemporary $L 2$ varieties}

The expression of negation in the L2 varieties of the Surinamese Creoles is similar to that found in the L1 varieties. In the L2 varieties (7), as in the practices of urbanized younger EMs, the EMC and the Sranan clausal negators are used interchangeably.

a. Nownow mi ná e go na a munde [...] bika mi án nownow 1S NEG IMPF go LOC DET Monday because 1S NEG be de ya tok. (HM) PAST COP here D

'Now, I'm not going on Monday because I wasn't here, ok.'

b. No mi no o teki a kans ye! (HM)

no 1S NEG FUT take DET chance D

'No, I will not take the chance!'

L2 varieties also make use of constituent negation (8a). In contrast to L1 varieties, however, constituent negation does not appear to be very common in L2 varieties. Furthermore, in L2 varieties non-fronted negative constituents in clause initial position may co-occur with clausal negation (8b-c), as in Sranan (3) above, but unlike the L1 EMCs. In fact, there is only one example in the L2 corpus in which a negative constituent occurs without a clausal negation marker (8d).

(8) a. I ná abi ná wan pikin?

2S NEG have NEG one child

'You don't have a child?'

b. Beina ná wan sama ná e taki faansi enke mama bee tongo. nearly NEG one person NEG IMPF talk French like mother belly tongue 'Nearly no one speaks French as their mother tongue.' (FM)

c. No wan sma no sabi fa mi e meki resept.

NEG one person NEG know how 1S IMPF make respect

'No one knows how I respect people.'

d. No wan tra sani de, wan bureau, yu go a tapu. (FM) NEG one other thing COP a office $2 \mathrm{~s}$ go LOC top

'There is nothing else. An office, you go upstairs.'

Clausal negation is also combined with inherently negative quantifiers such as neks ( $<$ Dutch niks 'nothing') and no(o)iti (< Dutch nooit 'never') in L2 varieties (9). Such constructions are much more frequent in all L2 varieties than those involving ná wan/no wan. 
(9) a. mi no abi neks fu taki. (PN)

1S NEG have nothing for say

'I don't have anything to say.'

b. nooiti mi ná $e$ denki fu ogi. (KG)

never 1S NEG IMPF think for bad

'I never intend to do bad things.'

In contrast to L1 varieties, negative quantifiers may occur without clausal negation in both clauseinitial and clause-final position in L2 varieties (10).

(10) a. gi mi a sani, noit $m i$ luku a sani. (SL) give me DET thing never $1 \mathrm{~s}$ look DET thing

'Give me that the thing, I have never looked at the thing.'

b. ma na fu dati mi taki neks.

but FOC for that 1s say nothing

'That's why I said nothing.'

The comparison shows that L2 varieties differ from L1 varieties in the relative frequency of use of negative constituents and quantifiers and the rules governing their co-occurrence with clausal negation. The placement of negative constituents and quantifiers in L2 varieties mainly serves the function of focus marking which is reminiscent of the behavior of negation markers in the BV as reported by Dimroth \& Watorek (2000) and Dimroth et al. (2003).

\section{3. Negation in historical sources}

Basic negative clauses do not differ much across the various sources of Early Sranan; the negation operator no is placed in between the subject and the verb, preceding markers of tense mood and aspect, and auxiliaries (11a). ${ }^{5}$ In copula-less clauses, no precedes the nominal predicate (11b).

(11) a. effi mi no ben takki gi ju, ju $\underline{\text { no }}$ ben sa sabi. (Sch 1783:15)

if 1S NEG PAST talk GIVE $2 \mathrm{~S}$ 2S NEG PAST FUT know

'If I didn't tell you, you would not have known.'

b. jou no meester vor mi. (CR 1707)

\footnotetext{
${ }^{5}$ The negation operator is occasionally represented as $n a$ in Schumann's (1783) dictionary and Van Dyk's (c.1765) language manual. Although these occurrences may just be unintentional spelling errors by the authors, or the type setter in the case of van Dyk, they remind us of the EMC negation operator ná. Since both Schumann and van Dyk include many features that can be associated with the vernacular of the population of African descent, in particular of the enslaved people on the plantations (van den Berg 2007), it may very well be the case that $n o$ and $n a$ were negation operator variants in some of the plantation varieties of Early Sranan.
} 
2S NEG master of $1 \mathrm{~S}$

'You are not my master.'

Combinations of clausal negation and negative quantifiers such as notti 'nothing' ( $<$ Engl. nothing) and nimmere 'never' (<Dutch nimmer 'never') are encountered in most of the sources, see for example (12).

(12) a. mi no habi notti va takki. (Sch 1783:125)

1S NEG have nothing to say

'I have nothing to say.'

b. Mino jerri zo wan zant nimmere (VD c1765: 79)

1S-NEG hear so a thing never

'I have never heard such a thing.'

However, when the negative quantifier occurs in clause-initial position, the clausal negation is dropped, as in (13).

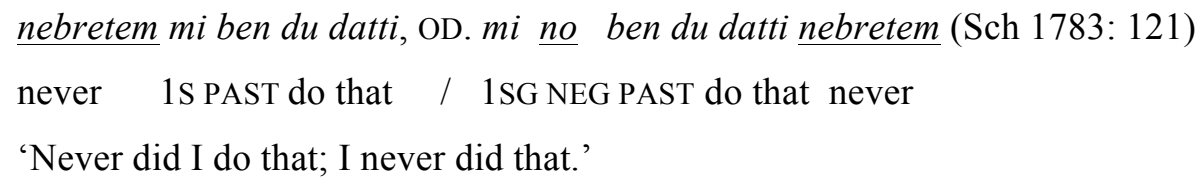

The negative construction no wan 'NEG one/a' differs from notti 'nothing' and nimmre/nebretem 'never' in that it cannot co-occur with clausal negation in basic negative sentences. Instead we find constructions such as (14a-b). ${ }^{6}$ Furthermore, we find examples such as $(14 \mathrm{c})$, where the preposition $n a$ splits up the negative construction no wan, while the meaning of the entire construction appears unaffected by this change.

(14) a. mi no de go wanpeh, OD. No wan peh mi de go

1S NEG IMPF go one/a-place/ NEG one/a place 1S IMPF go

'I am going nowhere.'

(Sch 1783: 134)

b. dem no sa doe joe wan santie (CR 1760)

$3 \mathrm{P} \quad \mathrm{NEG}$ FUT do $2 \mathrm{~S}$ a thing

'They will not harm you.'

c. $\underline{\text { no }}$ wan peh, $\underline{\text { no }}$ na wan peh (Sch $1783: 133)$

\footnotetext{
${ }^{6}$ The only instances in which clausal negation co-occurs with no wan in the sources is when the negated constituent is emphasized by means of placing intonational stress on wan. In Schumann's (1783) dictionary intonational stress is orthographically marked. In other sources, it can be inferred from the context that wan is stressed.
} 
NEG one place NEG LOC one place

'nowhere'

These findings suggest that no wan was not a lexicalized negative quantifier that modified nouns in Early Sranan, even though pronominal no wan 'no one; nobody' (< Eng. no one) is encountered from the mid- $18^{\text {th }}$ century onwards. They further suggest a more syntactic rather than a more focus-sensitive motivation underlying the use of the clausal negation. The clausal negator seems to overrule the use of the constituent negator, and the negator no no longer appears adjacent to the item it has in focus.

\subsection{Negation in L1, $L 2$ and the historical sources}

Our discussion of the expression of negation revealed some remarkable similarities between L1 EMC and Early Sranan varieties. In both sets of varieties a negated constituent in non-clause-initial position combines with preverbal clausal negation. In clause-initial position, it only combines with clausal negation when it is under focus. This contrasts with modern Sranan and contemporary L2 varieties where clause-initial negated constituents may always combine with clausal negation. We hypothesize that this difference between L1 EMC/Early Sranan and modern Sranan/L2 varieties is due to the latter having being heavily influenced by other languages for a prolonged period of time, and therefore involving a greater degree of variation. Finally, modern L2 varieties differ from L1 EMC and L1 Sranan in that they do not make frequent use of constituent negation; preverbal negation is the preferred strategy. This is also true for Early Sranan. This may be because of convergence: In the L1 linguistic system, preverbal negation is the unmarked strategy to express negation, while constituent negation is the marked strategy, bringing an item into focus in an explicit manner. In L2 learning the preverbal position is the pre-focus position, where the negator occurs when it begins to act as a focussensitive operator (Dimroth \& Watorek 2000; Dimroth et al. 2003). Because the syntactic and focussensitive positions overlap, and constituent negation is relatively marked, the preverbal position is the preferred position for the negator. Thus, we conclude that the domain of negation must have stabilized early onwards.

\section{Tense and aspect}

Tense and aspect are studied extensively in L1 and L2 acquisition research, uncovering a strong relationship between inherent lexical aspect of verbs and the acquisition of tense-aspect morphology (Andersen \& Shirai 1996; Sugaya \& Shirai 2007; Bardovi-Harlig 2000). The Aspect hypothesis summarizes this relationship, predicting that at the early stages of acquisition, learners predominantly use past tense and perfective aspect forms with punctual and telic verbs and progressive aspect forms with activity verbs (Sugaya \& Shirai 2007; Andersen \& Shirai 1996). Li \& Shirai (2000: 50) summarize the predicted order of development of tense-aspect morphology across different types of verbs as follows: 
Table 2. The development of tense-aspect morphology

\begin{tabular}{llllllll}
\hline & State & & Activity & & Accomplishment & & Achievement \\
\hline (Perfective) Past & 4 & 4 & 3 & 4 & 2 & 4 & 1 \\
Progressive & $?$ & 4 & 1 & $\rightarrow$ & 2 & $\rightarrow$ & 3 \\
Imperfective & 1 & $\rightarrow$ & 2 & $\rightarrow$ & 3 & $\rightarrow$ & 4 \\
\hline
\end{tabular}

Note: Numbers represent order of acquisition, from the earliest (1) to the latest (4).

Below the expression of tense and aspect in L1, L2 varieties and Early Sranan is studied from this developmental perspective.

\subsubsection{Imperfective aspect in the contemporary $L 1$ varieties}

Most Surinamese Creole L1 varieties express imperfective aspect with the element $e$ (Winford \&

Migge 2007: 85-91). ${ }^{7} E$ can occur with a wide range of verbs such as state verbs (STATE), activity verbs (ACT), accomplishment-denoting verbs (ACC) and achievement-denoting verbs (ACH) expressing a progressive (PRO), habitual ( $\mathrm{HAB}$ ), continuous (CON) as well as inchoative (INC) occurrence of the state or event denoted by the main verb.

a. CON+ACT pe! Da a mi anga $i \quad \underline{e}$ nyan a
Q place then FOC $1 \mathrm{~S}$ with $2 \mathrm{~S}$ IMPF eat DET
pina fu saanan.
suffering POSS Surinam
'What! You and I suffer/get the bad part of Surinam.'

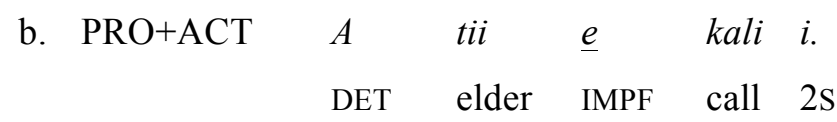

'The elder is calling you.'

$\begin{array}{llllllll}\text { c. } \mathrm{HAB}+\mathrm{ACT} & M i & n a ́ & \underline{e} & \text { go } & a & \text { ini } & \text { sama taki. } \\ & \text { 1S } & \text { NEG } & \text { IMPF } & \text { go } & \text { LOC } & \text { in } & \text { person talk }\end{array}$

'I don't typically interfere with people's discussions.'

d. INC+ACC Den $\underline{e}$ poli den pikin.

3P IMPF spoil DET child

'They are spoiling the children.'

e. CON+STATE Tii $A$. $\underline{e}$ de fi en so mooi(n).

\footnotetext{
${ }^{7}$ Seuren (1981) was perhaps the first to trace the imperfective aspect marker $(d) e$ to the copula/existential verb de which ultimately derives from the English locative adverb there (Smith 1987). It is being debated whether this process took place in Suriname (Arends 1989; Migge 2002) or elsewhere (Smith 2001), as it could have been imported by enslaved Africans prior to their arrival in Suriname. In Saamaka imperfective aspect is expressed by ta which derives from English stand (tan in the older sources).
} 
Elder A. IMPF COP for $3 \mathrm{~S}$ so nice

'Elder A is doing well.'

f. $\mathrm{PRO}+\mathrm{ACH} I$ e feni mma B. teki.

2S IMPF find elder $B$ take

'You managed to secure elder B for yourself.'

$E$ may also express (imminent) future with motion verbs.

(16) [A asks B if she wants something to eat; B declines saying that she intends to leave, i.e. will be leaving soon:]

B: $M i \underline{e}$ gwe.

1S IMPF leave

'I'll leave to go upriver tomorrow.'

\subsubsection{Imperfective aspect in $L 2$ varieties}

$E$ is also found in similar contexts in L2 varieties (17).

(17) a. INC+ACC A uwiiri seefi $\underline{e}$ fatu tok. (RA)

DET hair self IMPF fat right

'The hair itself is getting thicker, right.'

b. $\mathrm{PRO}+\mathrm{ACT} I \quad \underline{e}$ yoku. $\quad(\mathrm{Krl})$

2S IMPF joke

'You are joking.'

c. $\mathrm{HAB}+\mathrm{ACT}$ Di den $\underline{e}$ kari bita uwiiri. $(\mathrm{Krl})$

which 3P IMPF call bitter leave

'Which they refer to as bitter leave.'

d. CON+STATE da mi go aksi wan man sa $\underline{e}$ sabi. (Kr)

then $1 \mathrm{~S}$ go ask one man who IMPF know

'Then I go and ask a man who is knowledgeable.'

e. $\mathrm{PRO}+\mathrm{ACH} I \quad \underline{e}$ bay wan machine. $(\mathrm{Krl})$

$2 \mathrm{~S}$ IMPF buy one machine

'You are buying a machine.'

In L2 varieties, $e$ may also receive an immediate future interpretation.

(18) La Poste seefi mi $\underline{e}$ boon!(Ww) 
post.office self 1S IMPF burn

'Even the post office I will burn down!'

The main difference between L1 and L2 practices is that $e$ appears to be optional in L2 varieties. Most L2 speakers use $e$ in more than $60 \%$ of the cases and few use only or predominantly $\varnothing$ (Migge \&

Léglise in prep.). At this stage, it appears that absence of $e$ is more common if the verb is preceded by the Sranan negative marker no.

(19) a. a no $\varnothing$ sabi pe mi e tan. (PiM)

3S NEG IMPF know where 1S IMPF stay

'He doesn't know where I live.'

b. solanga a no $\varnothing$ puru stoff, a bun moro bun fu tapu en.

so.long 3S NEG IMPF pull puss $3 \mathrm{~S}$ good more good for cover $3 \mathrm{~s}$.

'As long as it does not have puss, it is better to cover it.'

In terms of the Aktionsart of the verb, absence of $e$ appears with a wide range of verb types - absence is frequent with activity verbs, but they are also most frequent in the data.

(20) a. CON+STATE a beibi $\varnothing \quad$ sibii? (PiN)

DET baby IMPF sleep

'The baby is sleeping.'

b. PRO+ACT Mi $\varnothing$ takitaki nanga a uman $d a \quad u \quad \varnothing \quad$ taki

$\mathrm{HAB}+\mathrm{ACT}$ 1S IMPF talktalk with DET woman then 1P IMPF talk creole. $(\mathrm{Kr})$

creole

'When I'm chatting with my wife, then we generally speak in

Haitian Creole.'

c. CON+STATE Ma kande den man $\varnothing$ feele $f u$ den $\varnothing$ feele but maybe DET man IMPF afraid for 3P IMPF afraid

fu $\quad$ a bubu. (P)

for DET tiger

'Maybe these people are afraid of the tiger?'

d. PRO+ACC suma Ø bau a oso? Na Englishman nanga

who IMPF build DET house FOC Englishman with

brasilian. (G1)

Brazilian

'Who is building houses [in Guyane]? Guyanese and Brazilians.' 
e. HAB+STAT Eya $m i$ be go luku fa Cayenne $\varnothing$ tan.(G1)
yes $1 \mathrm{~s}$ PAST go look how Cayenne IMPF stay

'Yes, I went to see how it is in Cayenne.'

In L2 varieties, unlike L1 varieties, $e$ may be used to convey future with motion (21a) and non-motion verbs $(21 b-c)$.

(21) a. Bernie Speer kon, a taki a no $\underline{e}$ kon moro. (ST) Bernie Speer came 3S talk 3S NEG IMPF come more

'Bernie Speer came here and she said that she is not going to come again.'

b. $u$ ná $\underline{e} \quad$ si tonton $R$. fosi $u \quad \varnothing \quad$ gwe! (PiN) we NEG IMPF see uncle $\mathrm{R}$ first $1 \mathrm{P}$ IMPF/FUT leave

'We won’t see uncle R. before we'll leave.'

c. [talking about life and death]

Na vakansi $u \quad \underline{e}$ teki, $u \quad \underline{e}$ abi fu dede. $(\mathrm{Ku})$

FOC holiday 1P IMPF take 1P IMPF have for die

'It's holidays that we are taking [right now, but] we're going to die.'

\section{1. 3. Imperfective in early sources}

In Early Sranan, imperfective aspect meanings are expressed by (spelling variants of) de, auxiliaries such as tan 'to stay' or begin 'to begin; to start', or they are not expressed at all (zero, Ø). For limitations of space, we restrict our discussion to de. As in L1 varieties, it occurs with a wide variety of verbs in the sources, expressing a progressive, habitual, continuous as well as inchoative occurrence of the state or event denoted by the main verb. Some examples of de with state verbs, activity verbs, accomplishment verbs, achievement verbs as well as semelfactives are presented in (22). ${ }^{8}$

$\begin{array}{llll}\text { a. HAB+STATE: } & \text { Gado } & \text { de sabi alla membre va wi, bevo wi pulu } \\ & \text { god IMPF know all thought of 1P before 1P remove } \\ & \text { muffe na tongo (Sch 1783: 116) } \\ & \text { word LOC tongue }\end{array}$

'God learns all our thoughts, before we utter them.'

b. INC+ACH: $\quad d a$ siri de gi heddi (Sch 1783:63) the seed IMPF give head 'The seed is germinating.'

c. PRO+ACT: watra de pissi na dem hai (Sch 1783:56)

\footnotetext{
${ }^{8}$ A semelfactive is a type of verb that is used in reference to an event that happens only once.
} 
water IMPF urinate LOC $3 \mathrm{P}$ eye

'Water is running from their eyes; they are crying.'
d. PRO+SEM: $\quad a$ de meki koffokoffo (Sch 1783: 84) ${ }^{9}$
3S IMPF make cough.IDEO
'He is coughing.'
e. $\mathrm{PRO}+\mathrm{ACC}:$ mi de go na dorro
1S IMPF go LOC outside
(Sch 1783: 33)
'I am going outside.' the chicken IMPF sleep sit.down LOC egg top
'The chicken is sitting on the egg.' (Sch 1783: 39)
f. CON+STATE: da vool de slibi (od. siddom) na eksi tappo

While the examples in (22) show that de is an established imperfective aspect marker by the end of the $18^{\text {th }}$ century, other examples reveal that its use is optional rather than categorical throughout the $18^{\text {th }}$ century. All sources contain instances of unmarked verbs, while the discourse context suggests that de would have been appropriate if it had been obligatory. For example, we find in Nepveu (1770):
(23) a. a de wakka langa him (N 1770: 277)
3S IMPF walk with $3 \mathrm{~s}$
'He is having an affair with her.'
b. a fourfouro langa him (N 1770: 277)
$3 \mathrm{~s}$ steal with $3 \mathrm{~s}$

'He is having an extramarital affair with her.'

Aspect is marked in example (23a), while it is not marked in (23b). Example (23a) is a paraphrase of the sentence 'he/she has a relationship with him/her'; (23b) conveys the same meaning, but qualifies the relationship as an extramarital one. Towards the end of the $18^{\text {th }}$ century $d e$ is used increasingly to mark imperfective aspect. For example, more instances of de are found in Weygandt's language primer, which is an extended revision of Van Dyk's (c1765) language primer, than in the original Van Dyk. A detailed comparison of these sources (van den Berg in prep.) reveals that Weygandt corrected some uses of $d e$ in Van Dyk. He also inserted de where unmarked verbs occur in Van Dyk, compare (24a) with (24b).
(24) a. Joe jam morre metti liki briddi (VD 1765:27)
$2 \mathrm{~s}$ eat more meat like bread

\footnotetext{
${ }^{9}$ While the reduplication may give the impression of non-semelfactivity, meki koffokoffo can be used as a semelfactive ('to give a cough' as well as a non-semelfactive ('to be coughing').
} 
$\begin{array}{lllll}\text { b. Joe } & \underline{\text { de }} & \text { n’jam moro metie lekie brédee (Wey 1798: 95) } \\ \text { 2S IMPF eat more meat like bread }\end{array}$

'You are eating more meat than bread.'

In conclusion, we summarize that $d e$ emerged as an imperfective aspect marker from the mid- $18^{\text {th }}$ century onwards, but it appears to be an optional, rather than a categorical item. Further research is needed to determine what precisely governs the use of $d e$ in Early Sranan.

\subsection{Expression of past time reference}

The Surinamese Creoles have a relative tense system in which the tense locus may be either the moment of utterance (speech time) or some other reference point.

\subsubsection{Contemporary L1}

In the contemporary Surinamese Creoles past time reference is either expressed by the particles ben (Sranan) and be (EMC) which precede the verbal head (25a) or by the unmarked verb (25b) optionally modified by temporal adverbials. Constructions using the unmarked verb occur once reference time has been established (cf. Huttar \& Huttar 1994: 491-492).

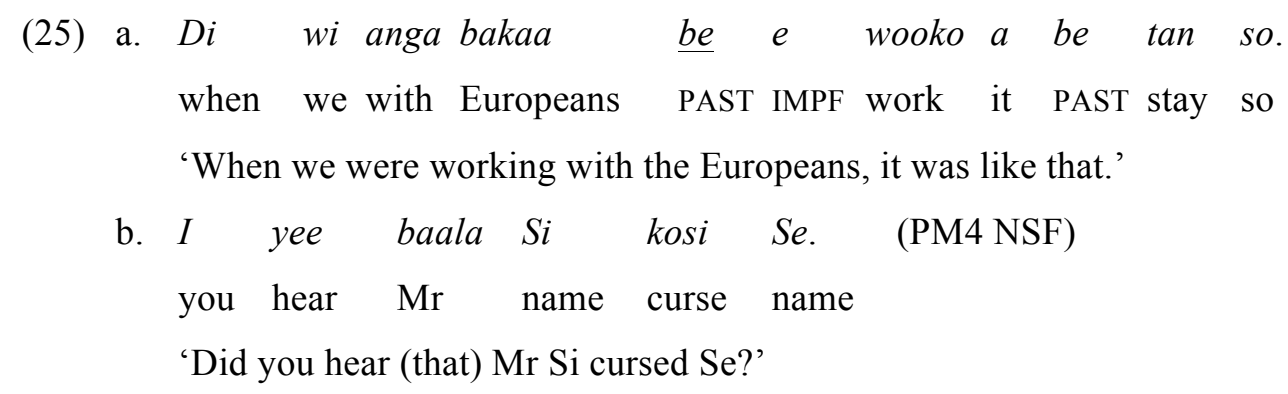

Verbs that have more of a state-type interpretation such as $s a b i$ 'to know' and tan 'to stay' generally require be to locate the state in the past because their default interpretation is present time reference. When ben/be precede an activity-denoting verb in a past context, ben/be locate the activity as having taken place prior to the point of reference in the past, i.e. 'a past before past' or background information (cf. Winford 2000: 401 for Sranan). If ben/be are combined with $o$, sa or wani, they express a hypothetical or counterfactuality meaning (cf. Winford 2000: 409).

\subsubsection{Past time reference in $L 2$ varieties}

The situation seems to be relatively similar in L2 varieties where predicates are marked for past time by the marker be or ben. However, once the time frame has been set, such marking is no longer necessary, particularly with activity-denoting verbs. 
(26)
A: Saide $i$ be kon a Guyane?(FM)
why $2 \mathrm{~S}$ PAST come LOC French Guiana

'Why did you come to French Guiana?'

B: bika mi án be wani meki suudati, da mi be sabi because 1S NEG PAST want make soldier then 1S PAST know wan association na Soolan neen mi $\underline{\varnothing}$ kon $f i$ wooko na a one association LOC St. Laurent then 1s come for work LOC DET association, neen den $\underline{\varnothing}$ tya mi kon a suudati a Cayenne. Association then $3 \mathrm{P}$ carry $1 \mathrm{~s}$ come LOC soldier LOC Cayenne

'Because I didn't want to go to the army. So I knew an association in St.

Laurent, thus I came to work there. They made me go to the army in Cayenne.'

There are a number of instances in the L2 data where the past marker appears to be overused in that the timeframe was established, but speakers still continued to use be instead of the unmarked verb form.

(27) A: ohoo ma $i$ seefi, $i$ kweki a Haiti anda? (Kr)

$\mathrm{Oh}$ but $2 \mathrm{~s}$ self $2 \mathrm{~s}$ raise LOC Haiti over-there

'Oh, but you yourself, you grew up in Haiti?'

B: ai baya dati na langa tin toli. Ai mi ben kweki na Haiti Yesfriend that PRE long time story yes 1S PAST raise LOC Haiti wel en baka dati mi be kon na Sranan.

Well and back that $1 \mathrm{~S}$ PAST come LOC Sranan

'Yes my friend, that's from a long time ago. Yes I grew up in Haiti and then I came to Surinam.'

The L2 corpus also includes some examples where be is used as a 'past before past' or background marker (28a-b) and others where it marks hypothetical or counterfactuality in conditional clauses (28c), as in L1 varieties.

(28) a. mi gi a man feifi euro a tra dei, $i$ sabi a 1s give DET man five Euro LOC other day you know DET man fu tyari a sani, a taki a be wani wan dringi a man for carry DET thing $3 \mathrm{~S}$ say $3 \mathrm{~S}$ PAST want one drink $3 \mathrm{~S}$ ná be abi pikin moni. (StL)

NEG PAST have small money

'I gave the guy five Euro the other day, you know the guy who was to bring 
the thing, he said he wanted to get a drink, he didn't have any change.'

b. No na ini wan bigi boto. A abi ala sani $u$ e wroko no LOC in a big boat $3 \mathrm{~S}$ have all things 1P IMPF work sigisi wrokoman kapten, a kapten be de wan six workers capitain DET capitain PAST COP a Jampanner $y a$, mi be de barman. A no sowmaar a Japanese here 1S PAST COP barman 3S NEG nothing DET boto dati a no somaar $[\ldots]$ (PI) boat that $3 \mathrm{~S}$ NEG nothing 'No, inside a big ship. It had everything. We were six crew members and a captain, the captain was a Japanese, I was the barman, it wasn't any kind of ship.'

c. A no so, mi be $\quad$ o $g i \quad y u, \quad y u \quad e \quad$ kali $m i$ $3 \mathrm{~S}$ NEG so $1 \mathrm{~S}$ PAST FUT give $2 \mathrm{~S} 2 \mathrm{~S}$ IMPF call $1 \mathrm{~S}$ giiliman, $\quad y u$ no sabi. (StL) greedy.person 2S NEG know 'It's not like that. I would have given you, [but then] you called me a greedy person, you don't know.'

\subsubsection{Early Sranan}

Relative past is expressed by variants of ben in the early Sranan sources. Prototypically, ben locates a certain situation as occurring prior to the time reference point established in the discourse, that is the moment of speech or some reference point in the past. In the dialogue represented in (29) the reference point is the period of departure from France. Thus, ben indicates that the talking took place prior to the leaving.

$$
\begin{aligned}
& \text { [A] Hoe zan den ben takki da.tem joe kommote na frans } \\
& \mathrm{Q} \text { thing 3P PAST say when } 2 \mathrm{~S} \text { come.out LOC France } \\
& \text { konderi. } \\
& \text { country } \\
& \text { 'What did they say when you were leaving France?' } \\
& \text { [B] Den ben takki van noeffe zomma disi ben go trouw } \\
& \text { 3P PAST say of many person REL PAST go marry } \\
& \text { 'They spoke of many people who were getting married.' (VD c1765: 36) }
\end{aligned}
$$

The earliest attestation of ben is Herlein's (1718) text, see (30a) below. Nepveu (1770) corrects this sentence, leaving out ben among other alternations (30b). Indeed, sendi 'to send' is a non-stative verb; 
when unmarked it usually expresses 'past time reference', if the point of reference is speech time. Example (30c) is a dialogue from Weygandt's manual that is similar to the Herlein dialogue.

(30) a. No mie ben benakese ta entre ples a reddiwen (HL 1718: 122$)^{10}$ NEG 1S PAST send-ask SAY other please again ?

'No, I have already send to ask someone else if it would please her.'

b. no mi sendi hakisi, na tara plessi a reddi (N 1770:274)

NEG $1 \mathrm{~S}$ send ask LOC other please/place already

'No, I've already asked somewhere else' or:

'No, I've already asked someone else if it would please her.'

c. [A] Joe dé go kiesie fiesietie na joe tidee sabathem? $2 \mathrm{~S}$ IMPF go get company LOC $2 \mathrm{~s}$ today evening

'Are you receiving company at your place this evening?'

[B] Miesie Annaatje ben sen aksie mie ofoe mie sa dé na Miss Anna PAST send ask $1 \mathrm{~S}$ if $1 \mathrm{~S}$ FUT COP LOC hoso, ofoe. Wan tra soema kom (Wey 1798:121) house if one other person come

'Miss Anna send (someone) to ask me if I'll be at home or if another person is coming.'

Although the point of reference is not made explicit in the examples in (30), based on the discourse context it can be argued that it is not the time of speaking, but some time in the past. Thus, Nepveu's correction may not necessarily be an improvement; he may have mistaken the reference point as speech time under the influence of his native tongue.

Similar to a secondary (modal) use of ben in contemporary L1 Sranan (Winford 2000; Wilner 1994), Early Sranan ben can convey a sense of hypotheticality or suggestion, to 'soften' the effect of a piece of advice, an invitation or a request, as in the example below. It is taken from the opening lines of a dialogue between two ladies, one visiting the other.

$\begin{array}{lllllllll}\text { (31) Mi ben } & \text { wan kom na misi na disi zabatim. } & \text { (VD c1765: 32) } \\ \text { 1S PAST want come LOC lady LOC this evening } & \end{array}$

'I would like to visit the lady this evening.'

\subsection{Conclusion}

\footnotetext{
${ }^{10}$ Benakese is a contracted serial verb construction, sen(i) aksi, which roughly translates as 'to send to ask'. The first verb sen $(d) i$ is misprinted as ben. For a more detailed discussion, see van den Berg (2007) and Arends (1995). The word wen is unknown.
} 
There are several interesting similarities and differences between the use of the imperfective aspect marker in the three data sets. Unlike the predictions presented in Table 1, our data do not exhibit a strong relationship between inherent lexical aspect of verbs and the occurrence of tense-aspect morphology. Our findings show that in both contemporary L2 varieties and Early Sranan the imperfective marker can occur with all possible types of verbs, expressing all possible kinds of aspectual meanings. The main difference is that unlike the contemporary L1 varieties it is optional in the contemporary L2 varieties and Early Sranan. It is not fully understood at present what precisely governs its distribution in these varieties. Two explanations suggest themselves. First, it may be possible that the distribution of the imperfective marker is determined by factors such as the presence of the negation operator and by discourse or pragmatic factors. This would explain why the imperfective marker is not obligatory: Its occurrence is not syntactically motivated but rather driven by the speaker's desire to underscore the status of the state/event in the discourse and/or by whether or not temporal information is easily recoverable from the context (cf Benazzo 2009: 15). Second, the variability in the presence of TMA markers may also be indicative of the fact that the use and functions of the imperfective marker were/are not yet fully conventionalised in early Sranan and contemporary L2 varieties. Essentially, they would be representing earlier developmental stages and the L1 varieties would represent later stages. For instance, Slobin (2004) based on a comparison of the development of the future marker in Tok Pisin and TMA markers in Nicaraguan sign language that developed from several varieties of Home Signs and Benzzo \& Starren (2007) based on the development of interlanguage systems of learners of Dutch and French conclude, that variation between grammatical morphemes and adverbial TMA marking is typical of emerging linguistic systems developed by L2 speakers. Slobin (2004) credits their obligatory use to the agency of children acquiring the system as an L1. This has strong parallels with our case suggesting that the obligatory use of the Imperfective marker in L1 Eastern Maroon varieties was due to nativization. Further research is needed to clarify this.

The use of the relative past tense marker in the contemporary L1, L2 and Early Sranan varieties is very similar, although there is some indication of overuse in contemporary L2 varieties and Early Sranan. This is not atypical of L2 practices (cf. also Siegel 2008).

\section{Conclusions and implications}

The findings presented in this paper show some remarkable similarities and differences between contemporary L1 and L2 varieties and Early Sranan. The three investigated areas of grammar are very similar in the three types of data. Each subsystem involves the same variants and their distribution is also broadly similar in the three types of data. This suggests that there is diachronic and synchronic continuity between these three varieties: The language(s) has/have not been subject to drastic change. Continuity between them is particularly clear in the area of negation where we find close resemblance in the distribution of negative operators and negative constituents between (some) L1 (varieties), L2 
varieties and varieties represented in the early texts. This suggests to us that some areas of grammar did not pass through several developmental stages, appear to have been little affected by L2 practices and consequently nativized quickly.

However, other subsystems of grammar such as imperfective marking and the use of the past time marker were subject to variation in the early sources. $E$ alternated with zero and in the case of the past marker there was some tendency of using ben as an obligatory rather than as a relative past marker. These patterns of variation resemble those found in L2 varieties in general and those in contemporary L2 varieties of the Surinamese Creoles in particular, but differ from contemporary L1 patterns. This suggests at least two things in relation to the impact of L2 practices on creole development. First, L2 practices affected some areas of grammar in the early varieties, possibly those areas whose makeup differed in the native languages of the early users and creators of the languages, but were subsequently levelled probably as a result of increased nativization. Second, some areas of grammar stabilized relatively slowly, supporting the view that creole grammars emerged gradually via several stages rather than abruptly (Arends 1989).

\section{Abreviations}

$\begin{array}{ll}\text { ACC } & \text { accomplishment-denoting verb } \\ \text { ACH } & \text { achievement-denoting verb } \\ \text { ACT } & \text { activity-denoting verb } \\ \text { BV } & \text { Basic Variety } \\ \text { CON } & \text { continuative aspect } \\ \text { COP } & \text { copula } \\ \text { D } & \text { discourse marker } \\ \text { DET } & \text { definite determiner } \\ \text { FOC } & \text { focus marker } \\ \text { FUT } & \text { future marker } \\ \text { GIVE } & \text { the serial verb 'give' } \\ \text { HAB } & \text { habitual aspect } \\ \text { IDEO } & \text { ideophone } \\ \text { IMPF } & \text { imperfective marker } \\ \text { INC } & \text { inchoative aspect } \\ \text { LOC } & \text { general locational preposition } \\ \text { NEG } & \text { negation marker } \\ \text { P } & \text { plural } \\ \text { PAST } & \text { past time marker } \\ \text { POSS } & \text { possessive marker } \\ \text { PRE } & \text { presentative marker }\end{array}$




$\begin{array}{ll}\text { PRO } & \text { Progressive aspect } \\ \text { Q } & \text { general question morpheme } \\ \text { REL } & \text { relative marker } \\ \text { S } & \text { singular } \\ \text { SAY } & \text { the serial verb 'say' } \\ \text { STATE } & \text { state-denoting verb } \\ 1 & \text { first person pronoun } \\ 2 & \text { second person pronoun } \\ 3 & \text { third person pronoun }\end{array}$




\section{Early Sranan Tongo Sources}

- Court Records 1667-1767. Nationaal Archief, The Hague. Inventaris van de archieven van de Raad van Politie (1669-1680) en de Raad van Politie en Justitie (1680-1683) en het Oud-Archief van het Hof van Politie en Criminele Justitie in Suriname (access code 1.05.10.02, inventory numbers 781948); Overgekomen brieven en papieren uit het archief van de Sociëteit van Suriname, 1683-1715 (access code 1.05.04.01, inventory numbers 212-240), 1751-1767 (access code 1.05.04.06, inventory numbers 286-335).

- Schumann, Christian Ludwig (1781) Die Geschichte unsers Herrn und Heilandes Jesus Christi, aus den vier Evangelisten zusammengezogen. Utrecht; MS 617.

- Schumann, Christian Ludwig (1783) Neger-Englishes Wörter-Buch. Moravian archives, Utrecht/Paramaribo; MS 648.

- Herlein, J. D. (1718) Beschrijvinge van de volksplantinge Zuriname: vertonende de opkomst dier zelver Colonie, etc. mitsgaders een vertoog van de Boschgrond, etc. Verrijkt met een landkaart (daar de legginge der Plantagien worden aangewezen) en kopere platen. Leeuwarden: Injema (2e druk). UB, Amsterdam. UBM: 1803 G 11.

- Nepveu, Louis (1762). Sranan version of the Saramaka Peace Treaty. Nationaal Archief, The Hague. Inventaris van de archieven van de Raad van Politie (1669-1680) en de Raad van Politie en Justitie (1680-1683) en het Oud-Archief van het Hof van Politie en Criminele Justitie in Suriname (access code 1.05.10.02, inventory number 66 , ff. $177 \mathrm{v}^{\circ}-183 \mathrm{v}^{\circ}$.

- Van Dyk, P. (c1765) Nieuwe en nooit bevoorens geziene onderwyzinge in het Bastert Engels, of Neeger Engels, Zoo als hetzelve in de Hollandsze colonien gebruikt word. Amsterdam: De Erven de Weduwe Jacobus van Egmont. Universiteitsbibliotheek Leiden: 1148 H 32.

- Nepveu, Jean or Jan (1770) Annotatien op de Surinaamsche Beschrijvinge van A 1718. MS.

Municipal Archives, Amsterdam.

- Weygandt, G. C. (1798) Gemeenzaame leerwyze, om het Basterd of Neger-Engelsch op een gemakkelyke wyze te leeren verstaan en spreeken. Paramaribo: W.W. Beeldsnijder. UB, Leiden; 799 E 18.

\section{REFERENCES}

Andersen, R. \& Shirai, Y. (1996). The primacy of aspect in first and second language acquisition: The pidgin-creole connection. In W. R. Ritchie \& T. J. Bhatia (eds), Handbook of Second Language Acquisition, 527-570. San Diego: Academic Press.

Arends, J. (1989). Syntactic developments in Sranan: Creolization as a gradual process. Unpublished $\mathrm{PhD}$ dissertation, University of Nijmegen.

Arends, J. (1995). Introduction to Part I. In J. Arends \& M. Perl (eds), Early Suriname Creole texts: A collection of 18th-century Sranan and Saramaccan documents, 11-71. Frankfurt/Madrid:

Vervuert. 
Bardovi-Harlig, K. (2000). Tense and Aspect in Second Language Acquisition: Form, Meaning, and Use. Oxford: Blackwell.

Benazzo, S. (2009). The emergence of temporality: from restricted linguistic systems to early human language. In R. P. Botha \& H. De Swart (eds), Language Evolution: the View from Restricted Linguistic Systems, 21-58 (LOT Occasional Series 10), Utrecht: LOT.

Benzzo, S. \& Starren, M. (2007). L'emergence de moyens grammaticaux pour exprimer les relations temporelles en L2. AILE $\mathrm{n}^{\circ} 25,129-158$.

Bickerton, D. (1981). Roots of Language. Ann Arbor: Karoma.

Bruyn, A. (1995). Grammaticalization in Creoles: The Development of Determiners and Relative Clauses in Sranan. Studies in Language and Language Use, vol. 21. Amsterdam: IFOTT [PhD. Dissertation University of Amsterdam].

DeGraff, M. (1999). Language Creation and Language Change: Creolization, Diachrony and Development. Cambridge: MIT Press.

Dimroth, C., P. Gretsch, P. Jordens, C. Perdue \& M. Starren (2003). Finiteness in Germanic languages. In C. Dimroth \& M. Starren (eds), Information structure and the dynamics of language acquisition, 65-93. Amsterdam: Benjamins.

Dimroth, C. \& Starren, M. (2003). Information Structure and the Dynamics of Language Acquisition. Amsterdam: John Benjamins.

Dimroth, C. \& Watorek, M. (2000). The scope of additive particles in basic learner languages. Studies in Second Language Acquisition $\mathrm{n}^{\mathrm{0}} 22,307-336$.

Eersel, H. (2008). Wiryan Winter (wan tori ini Sranan). http://www.schrijversgroep77.org

Essegbey, J. \& Bruyn A. (to appear). Moving into and out of Sranan. In H. Cuyckens, W. De Mulder, T. Mortelmans, \& M. Goyens (eds.), Variation and Change in Adpositions of Movement. (Studies in Language Companion Series). Amsterdam: John Benjamins.

Hendriks, H. (2005). The Structure of Learner Varieties. Berlin/New York: Mouton de Gruyter.

Huttar, G. \& Huttar, M. (1994). Ndyuka. London/NY: Routledge.

Klein, W. \& Perdue, C. (1997). The basic variety (or: Couldn't natural languages be much simpler?). Second Language Research $\mathrm{n}^{\mathrm{0}} 13,301-347$.

Kramer, M. (2009). Gradualism in the transfer of tone spread rules in Saramaccan. In R. Selbach, H. Cardoso \& M. van den Berg (eds.), Gradual Creolization. Studies Celebrating Jacques Arends (Creole Language Library Series 34), 189-217. Amsterdam: John Benjamins.

Lefebvre, C., White, L., \& Jourdan, C. (2006). L2 Acquisition and Creole genesis: Dialogues. [Language Acquisition \& Language disorders 42] Amsterdam: John Benjamins.

Léglise, I. (2007). Des langues, des domains, des régions, pratiques, variations, attitudes linguistiques en Guyane. In I. Léglise \& B. Migge (eds.), Pratiques et Representations Linguistiques en Guyane: Regards Croisés, 29-48. Paris: Editions IRD. 
Léglise, I. \& Migge, B. (2006). Language naming practices, ideologies and linguistic practices:

Toward a comprehensive description of language varieties. Language in Society n ${ }^{\circ}$ 35, 313-339.

Li, P. \& Shirai, Y. (2000). The Acquisition of Lexical and Grammatical Aspect. [Studies on Language Acquisition 16] Berlin/New York: Mouton de Gruyter.

Migge, B. (2002). The Origin of the Copulas $(d / n) a$ and $d e$ in the Eastern Maroon Creole. Diachronica $\mathrm{n}^{\mathrm{o}} 19,81-133$.

Migge, B. (2007). Codeswitching and Social Identities in the Eastern Maroon community of Suriname and French Guiana. Journal of Sociolinguistics $\mathrm{n}^{\mathrm{0}} 11,53-72$.

Migge, B. \& Léglise, I. (in prep.) Investigating Multilingual Communities. Language Choice and Use in a Creole Context. Cambridge: Cambridge University Press.

Migge, B. \& Winford, D. (2009). The origin and development of possibility in the creoles of Suriname. In R. Selbach, H. Cardoso \& M. van den Berg, (eds.), Gradual Creolization. Studies Celebrating Jacques Arends (Creole Language Library Series 34), 129-153. Amsterdam: John Benjamins.

Roberts, S. (2000). Nativization and the genesis of Hawaiian Creole. In J. H. McWhorter (ed.), Language Change and Language Contact in Pidgins and Creoles, 257-300. Amsterdam: John Benjamins.

Seuren, P. (1981). Tense and aspect in Sranan. Linguistics $\mathrm{n}^{0}$ 19, 1043-76.

Siegel, J. (2008). The Emergence of Pidgin and Creole Languages. Oxford: Oxford University Press.

Slobin, D. I. (2004). From Ontogenesis to Phylogenesis: What Can Child Language Tell Us about Language Evolution. In S. T. Parker \& C. Milbrath (eds.), Biology and Knowledge revisted: From Neurogenesis to Psychogenesis, 255-306. Mahwah, NJ: Lawrence Erlbaum Associates.

Smith, N. (1987). The genesis of the Creole Languages of Suriname. [PhD Dissertation University of Amsterdam]

Smith, N. (2001). Voodoo chile. Differential substrate effects in Saramaccan and Haitian. In N. Smith \& T. Veenstra (eds.), Creolization and contact, 43-81. Amsterdam: John Benjamins.

Smith, N. (2009). English speaking in Surinam. In R. Selbach, H. Cardoso \& M. van den Berg (eds.), Gradual Creolization. Studies celebrating Jacques Arends (Creole Language Library Series 34), 305-326. Amsterdam: John Benjamins.

Sugaya, N. \& Shirai, Y. (2007). The acquisition of progressive and resultative meanings of the imperfective aspect marker by L2 learners of Japanese: Transfer, Universals, or Multiple Factors? Studies in Second Language Acquisition n ${ }^{\circ} 29,1-38$. Cambridge: Cambridge University Press. van den Berg, M. (2007). A grammar of Early Sranan. Zetten: Manta. PhD Dissertation, University of Amsterdam.

van den Berg, M. (in prep.) 'Aspect in Early Sranan’ Diachronica.

van den Berg, M. \& Arends, Jacques (2004). ‘Court records as a source of authentic early Sranan'. In 
G. Escure \& A. Schwegler (eds.) Creoles, Contact, and Language Change. Amsterdam: Benjamins, 21-34

Veenstra, T. (2006). Modeling Creole Genesis: Headedness in morphology. In A. Deumert \& S. Durrleman-Tame (eds.), Structure and Variation in Language Contact (Creole Language Library 29), 61-84. Amsterdam: John Benjamins.

Wilner, J. (1994). Non-temporal uses of ben in Sranan Tongo. Paper presented at the conference of the Society for Caribbean Linguistics, Guyana, August 1994.

Winford, D. (2000). Tense and Aspect in Sranan and the creole prototype. In John H. McWhorter (ed.), Language Change and Language Contact in Pidgins and Creoles, 383-442. Amsterdam: Benjamins.

Winford, D. (2003). An introduction to contact linguistics. Malden, MA/Oxford: Blackwell.

Winford, D. \& Migge, B. (2007). Substrate influence on the emergence of the TMA systems of the Surinamese creoles. Journal of Pidgin and Creole Languages $\mathrm{n}^{0} 22,73-99$.

\section{French Abstract}

La contribution de la langue seconde (L2) à l'émergence de la genèse du créole est largement présumé. Cependant, l'impact de la langue seconde ne pourrait se limiter à la genèse du créole. Au Suriname les nouveaux arrivés étaient plus nombreux que les locuteurs natifs du créole pendant tout le 18 e siècle. A ce jour, les effets éventuels de la disproportion entre les locuteurs natifs et les nonnatifs sur le créole pendant sa genèse et ultérieurement sont à peine connus. Dans cet article nous avons combiné des données antérieures et contemporaines afin d'étudier l'impact de l'acquisition et l'utilisation de la L2 sur l'évolution des créoles. Nous examinons plusieurs aspects linguistiques du discours contemporains en créole des locuteurs natifs et non-natifs afin de nous éclairer sur les différences sous-jacentes du système de la langue première et seconde. Celles-ci sont ensuite comparées à leurs équivalents provenant de sources antérieures. Cette comparaison nous a permis de conclure que certains sous-systèmes du créole ont davantage été influencés par l'acquisition de la langue seconde que d'autres. 